\title{
DALFRÉ, Liz Andréa. Outras narrativas da nacionalidade: o movimento do Contestado. Curitiba: SAMP, 2014. 236 p.
}

\author{
Aline Pinheiro ${ }^{1}$
}

- Enviado em 01.10.2016

- Aprovado em 03.12.2016

A Guerra do Contestado foi o conflito armado na região fronteiriça entre os estados do Paraná e de Santa Catarina, de um lado a população da região e do outro os representantes do poder estadual e federal brasileiro, o enfrentamento durou entre outubro de 1912 até agosto de 1916. 0 enfrentamento teve a situação agravada devido ao messianismo e pela crença dos revoltados de se tratar de uma guerra santa. Devido a importância de tal evento, Liz Dalfré produziu para sua dissertação do mestrado, em História na Universidade Federal do Paraná, o trabalho "Outras narrativas da nacionalidade: o movimento do Contestado". Apresentado no ano de 2004 a pesquisa foi transformada em livro 2014, mantendo o mesmo título, o que acrescentou mais ainda na discussão sobre a Guerra do Contestado, assunto o qual já tinha artigos, monografias, dissertações e teses sobre tal ou em obras que pesquisam o messianismo. A produção de Dalfré produz uma análise que desenvolve perspectivas até então não exploradas por outros autores, o que abre espaço para que novas pesquisas sejam realizadas pelo aspecto elaborado pela autora. A ideia da autora na sua obra é uma reflexão histórica sobre as representações produzidas no período do conflito, focando a análise dos textos produzidos pela imprensa periódica escrita paranaense e pelos militares os quais produziram narrativas do evento, sobre os revoltados e que demonstravam o interesse de determinadas instituições do período, na constituição de uma identidade nacional e regional.

\footnotetext{
${ }^{1}$ Graduada em Ciência Sociais pela Universidade Federal do Paraná. Mestranda em Sociologia pela Universidade Federal do Paraná. Endereço eletrônico: ali_pi_91@hotmail.com
} 
Dentre os autores visitados para a pesquisa estão: Maria Isaura Pereira de Queiroz, Maurício Vinhas de Queiroz, Duglas Teixeira Monteiro e Paulo Pinheiro Machado (sobre o movimento em si do Contestado), Nina Rodrigues, Silvio Romero e Euclides da Cunha (reconhecidos por pensar o Brasil e o seu povo), Marilene Weinhardt (que analisou em específico o Diário da Tarde), Herculano Teixeira D’Assumpção (que trabalha as diferenças culturais existentes entre os moradores do interior e das capitais), entre outros. A autora analisa em sua obra, além dos pensadores citados, o periódico Diário da Tarde, relatórios e livros escritos pelos militares que estiveram presentes no local do conflito.

No primeiro capítulo, "Contestado: um termo polissêmico", o foco da autora está em apresentar as diferentes formas que os pesquisadores contemporâneos observaram o Contestado, as diferentes representações dos acontecimentos e dos envolvidos, que inclusive, estão imbricadas na denominação por 'Contestado'. Levando isso em conta, o trabalho também usa fontes utilizadas anteriormente por outros autores, para repensar as significações que foram dadas ao Movimento "As representações sobre o Movimento, fazem parte da própria história do Movimento" (p. 25). Uma de suas preocupações dela foi estudar além dos pensadores do início do século XX, autores como: Maria Isaura Pereira de Queiroz com a obra 'O messianismo no Brasil e no mundo', Maurício Vinhas de Queiroz e o livro 'Messianismo e conflito social' e Duglas Teixeira Monteiro com o texto 'Os errantes do novo século', que pensaram para além da preocupação com a brasilidade e com os rumos do país. Em sua pesquisa ela aponta que foi a partir da década de 90 que trabalhos no campo da história, pensaram do ponto de vista analítico o conflito, como: reflexões sobre as narrativas e os termos recorrentes utilizados na constituição de um pensamento sobre o Movimento do Contestado. Outros pontos enfatizados pela autora são as narrativas e escritos que veiculam a relação do interiorano ou habitante do oeste do país (os quais sofreriam com o isolamento) como sendo 'bárbaro' versus o 'civilizado' do litoral. Tal característica, que também foi empregada sob o conflito de Canudos, é criticada por Dalfré pelo fato de várias narrativas assemelharem os movimentos de Canudos com o do Contestado.

No segundo capítulo, "Representações sobre o Contestado na imprensa regional", o cerne da discussão é o caso específico do discurso paranaense, analisando o periódico Diário 
da Tarde. 0 conflito do Contestado foi amplamente divulgado desde o começo pela a imprensa da capital paranaense, seja opinando, comentando ou noticiando. Tanto as posições tomadas pelos governos dos Estados envolvidos e do plano federal, visavam construir uma representação limitada dos sertanejos e dos militares. Na análise do periódico, a autora, também analisará o discurso reproduzido por esse, para mostrar o quanto este convergia ou não com o imaginário social do período, mas também um pensamento voltado para a "necessidade de construção de uma identidade regional, num momento em que os estados brasileiros adotavam a descentralização" (p. 50). Outra situação criada com a cobertura da imprensa escrita foi construção de representações sobre os brasileiros que almejava um ideal de nação e de Estado, nesse ponto específico a autora dedica um subitem para mostrar a importância de João Gualberto. Sobre a atuação deste personagem e de seus pares no serviço militar durante o conflito, o discurso adotado pelo Diário da Tarde era "um discurso dualista onde prevaleceu a ideia de bons e maus, forma encontrada também, para legitimar a repressão" (p.60), o que definiu as representações dos papéis dos dois lados, dos militares e dos revoltados, sendo o primeiro dados como bons e identificados com o Paraná. Outra figura importante, que Liz Dalfré busca revisitar as formas que este foi representado, está o monge José Maria. A própria representação geográfica foi observada na obra, já que está vincula noções de sertão (desafiador) e litoral, comuns no período, e que foram fundamentais para a construção da representação do Brasil e dos brasileiros, impregnando o imaginário da época tanto sob o olhar romantizado, como no olhar científico. Estes 'olhares' evidenciaram, segundo ela, o caráter evolucionista e positivista do imaginário do período e das representações propagadas no período.

No último capítulo, "Contestado: uma narrativa da nacionalidade" o eixo central é tentar compreender como se consolidou a busca por uma identidade nacional, já que o país acabará de passar por sérias mudanças sociais, econômicas e culturais durante o final do século XIX e começo do XX. Nesta busca, a representação dicotômica entre sertão e litoral, teve muito espaço. Nela o litoral considerado civilizado e moderno, também era visto como "parasita e superficial, como o sertão, apesar de atrasado e inculto, tornou-se a porção territorial autêntica, habitat do verdadeiro brasileiro." (109). A ideia que se passava era que o 
Brasil genuíno era encontrado no interior e não no litoral. Outro ponto importante tratado no corpo dessa unidade foram as imagens construídas pelos militares, na relação homem e espaço, o sertanejo e o "sertão", para classificação destes e como forma de explicação do conflito. A base para esta análise foram os relatórios militares e do Diário da Tarde, os quais produziram um imaginário sobre o Contestado, ainda mais quando comparadas com a relação que a obra de Euclides da Cunha e a revolta de Canudos, pois está relação foi apropriada por pensadores e do periódico Diário da Tarde para pensar o Movimento do Contestado.

A obra traz imagens e mapas para melhor análise das questões, além da enorme quantidade de autores que perpassam os temas abordados. Por tocar em um ponto não tão refletido sobre a Guerra do Contestado, o trabalho abre portas para futuras análises sob o mesmo tema. 